\title{
Grape seed proanthocyanidins extract promotes bone formation in a rat's mandibular condyle
} Makoto Ishikawa (Department of Pediatric Dentistry, Kyushu Dental College)

We studied the effects of dietary therapy with grape seed proanthocyanidins extract (GSPE) along with a high level of calcium on mandibular condyle bone debility, which was induced by a low-calcium diet. Forty Wistar male rats, 5-weeks old, were randomly divided into control (Co), low-calcium diet (LC), low-calcium/high-calcium diet (LCH), and low-calcium/high-calcium with supplementary GSPE diet (LCHG) groups for 6 weeks. Bone formation of the mandibular condyle was measured using peripheral quantitative computed tomography (pQCT). We concluded that dietary therapy with GSPE and high calcium intake led to recovery from mandibular condyle bone debility in rats.

\section{2.ラット味覚乳頭の味蕾におけるシナプトタグミン 1 の発現}

河野 亮子 (九歯大·顎口腔機能矯正学)

哺乳類の味蕾は I 型, II 型, III型および基底細胞に分類され， III型細胞は味神経と求心性シナプスを形成している. synaptotagmin 1 はシナプス小胞関連蛋白質の一種で, シナプス小胞での開口分泌の制御を行っている.しかしなが ら正型細胞での発現および機能は不明である。本研究は synaptotagmin 1 の味蕾での機能を明らかにすることを目 的として, synaptotagmin 1 の味蕾での発現様式の解明を試みた。 RT-PCR 法によりラット有郭乳頭に synaptotagmin 1 mRNA 発現が認められた。ささらに蛍光免疫組織化学染色により, 有郭, 葉状抢よび茸状乳頭の約 $10 \%$ の味蕾細胞および味蕾内や味蕾直下の神経線維での synaptotagmin 1 の発現が観察された。次に二重免疫染色

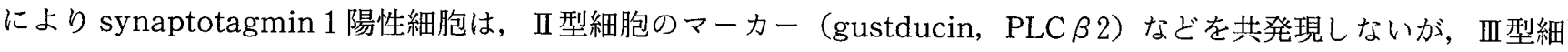
胞のマーカー（PGP9.5，NCAM）を共発現することが明らかとなった。これらの結果から, synaptotagmin 1 は开型 細胞でのシナプス小胞の開口分泌を制御することが示唆されるとともに, III型細胞を同定する新たなマーカー蛋白質 となりうることが示された。

\section{Expression of synaptotagmin 1 in the taste buds of rat gustatory papillae}

Ryoko Kohno (Department of Orthodontics, Kyushu Dental College)

Synapses between taste receptor cells and primary sensory afferent fibers transmit the output signal from taste buds to the central nervous system. Many kinds of synaptic vesicle proteins participate in synaptic vesicle cycles. One of them, synaptotagmin 1 binds $\mathrm{Ca}^{2+}$ phospholipids with high affinity and has a central role in $\mathrm{Ca}^{2+}$ regulated neurotransmitter release in the central and peripheral nervous system. However, the expression patterns of synaptotagmin 1, in rat taste tissues have not been revealed. Therefore, we examined the expression patterns of synaptotagmin 1 and several cell specific markers of type II and III cells in rat taste buds. RT-PCR assay showed that synaptotagmin 1 mRNA expressed in circumvallate papillae. In fungiform, foliate and circumvallate papillae, the antibody against synaptotagmin 1 gave labelling of a subset of taste bud cells and intra- and subgemmal nerve processes. Double-labelled experiments showed that synaptotagmin 1 positive cells co-expressed type III cell markers, PGP9.5 and NCAM. Intragemmal nerve processes positive for synaptotagmin 1 co-expressed PGP9.5. However, no synaptotagmin 1-expressing cells co-expressed type II cell markers, $\operatorname{PLC} \beta 2$ or gustducin. These results show that synaptotagmin 1 may play some regulatory roles in vesicle membrane fusion events with the plasma membrane at synapses of type III cells in rat taste buds. 